\title{
Evaluation of Efficiency of Echinodorus palaefolius (J.F. Macbr.) Involved in the Clarias gariepinus (Burchell, 1822) Culture for Water Quality Recovery and Fish Growth Support
}

\author{
Hany Handajani ${ }^{1, *}$, Ganjar Adhywirawan ${ }^{1}$, Soni Andriawan ${ }^{1}$, Dony Prasetyo ${ }^{1}$ and Boy \\ Ronald Mavuso ${ }^{2}$ \\ ${ }^{1}$ Department of Aquaculture, Faculty of Agriculture and Animal Science, University ofMuhammadiyah Malang, Jl Raya Tlogomas No. 246, \\ Malang 65144, Indonesia ${ }^{2}$ Ministry of Agriculture, P.O Box 162, Mbabane H100, Eswatini, Africa
}

Received: May, 15, 2021; Revised: Oct, 16, 2021; Accepted Nov, 11, 2021

\begin{abstract}
Intensive catfish [Clarias gariepinus(Burchell, 1822)] cultivation produces organic waste that decreases water quality. The aquaponics system utilizes fish waste for plant growth to produce useful and economical products. This study aims to analyze and evaluate the best density of Mexican sword plant/water Jasmine [Echinodorus palaefolius (J. F. Macbr.)] in reducing waste from intensive catfish aquaculture. The research method used a completely randomized design (CRD) with four treatments with three replications. A plastic tub with a size of $38 \mathrm{~cm} \times 12 \mathrm{~cm} \times 30 \mathrm{~cm}$ filled with sand was used for plant media, while for catfish rearing containers, a $70 \mathrm{~L}$ tub with a water volume of $40 \mathrm{~L}$ was used. The fish used in this experiment were catfish fry with a size of $7 \mathrm{~cm} \pm 0.8 \mathrm{~cm}$, a weight of $5.14 \mathrm{~g} \pm 0.45 \mathrm{~g}$, with a stocking density of one fry per liter. Catfish fry were fed with floating pellet feed of $30 \%$ protein content, and the feeding was done at satiation. The treatments were $\mathrm{T} 1=$ without plants, $\mathrm{T} 2=150 \mathrm{~g} \mathrm{~m}^{-2}$ plants, $\mathrm{T} 3=250 \mathrm{~g} \mathrm{~m}^{-2}$ plants, and $\mathrm{T} 4=350 \mathrm{~g} \mathrm{~m}^{-2}$ plants. Furthermore, all data were analyzed through ANOVA (One-way analysis of variance) and the Duncan's multiple range test to measure significant variations among the treatments using SPSS (version 17, USA). The results revealed that T4 was the best treatment in terms of nutrient removal efficiency of TAN, $\mathrm{NO}_{2}, \mathrm{NO}_{3}$, and $\mathrm{PO}_{4}$ at the rate of $23.80 \%, 48.19 \%, 52.99 \%$ and $26.11 \%$, respectively. Moreover, growth performances of fish fry fed diet in T4 also were significantly $(P<0.05)$ higher than other fishes of different treatments. Regarding these findings, E. palaefolius could work well to maintain water quality during C. gariepinus cultivation and even accelerated C. gariepinus growth at the end of the period.
\end{abstract}

Keywords: Aquaponics technology, Catfish, Economically valuable, Intensive culture, Mexican sword plant, Phytoremediation, Utilization waste, Water Jasmine

\section{Introduction}

Catfish [Clarias gariepinus (Burchell, 1822)] is a very popular commodity for cultivation in Africa, Indonesia, and several other countries in the world because of its fast growth, disease resistance, and wide geographical spread (Elesho et al., 2021). Consequently, catfish production in Indonesia has increased rapidly, accounting for $55691 \mathrm{t}$ in 2004 and climbed dramatically in 2014, reached $543774 \mathrm{t}$ (Zahidah et al., 2018). In addition, catfish production from 2017 to 2018 increased from $841.75 \times 10^{3}$ t to $1.81 \times 10^{6} \mathrm{t}$ (114.82 \%) (FAO, 2018).

In intensive fish cultivation, only about $80 \%$ of the feed given is consumed, while the remaining $20 \%$ will be wasted (not eaten), and of the $80 \%$ consumed, only about $25 \%$ will be retained. In comparison, the remaining $10 \%$ will be wasted through faeces, and $65 \%$ will be excreted as urine (Bureau and Hua, 2010). According to El-Shafai et al. (2007), in the intensive cultivation system of tilapia, the nutrients released are around $62 \%$ to $73 \%$ of the total nitrogen and $55 \%$ to $70 \%$ of the total phosphorus divided into particles dissolved. Furthermore, $\mathrm{N}$ and $\mathrm{P}$ waste can affect water quality parameters such as a decrease in the concentration of dissolved oxygen content and an increase in the concentration of carbon dioxide, ammonia, nitrite, and nitrate (Hlordzi et al., 2020). According to Keramat (2011), the resulting waste could increase dissolved and suspended organic matter in the feed residue, faeces and urine, negatively affecting fish growth even at specific toxic doses. Therefore, the deterioration of water quality leads to retard fish growth (Makori et al., 2017). In a review by Yavuzcan et al. (2017), water quality deterioration has a detrimental effect on fish physiology, growth rate, and feed efficiency, resulting in various diseases and even death. Based on those obstacles, it is necessary to find a solution to maintain water quality suitable for C. gariepinus, such as applying an aquaponics system.

Aquaponics is the process of maintaining aquatic organisms and plants in symbiosis into one system or several sub-systems (Goddek et al., 2019; Monsees et al., 2017; Pedersen et al., 2012), whereas treated water is circulated freely between aquaculture and hydroponic units in a single loop system (Goddek et al., 2019). The

\footnotetext{
* Corresponding author e-mail: handajani@umm.ac.id.
} 
principle of the aquaponics system is to utilize fish cultivation waste for plant growth and produce useful and economically valuable by-products (Somerville et al., 2014). The advantages of aquaponics technology compared to conventional fish cultivation technologies are to control water quality, high fish growth and production, and additional income from plants. Plants in aquaponics technology absorb nutrients from waste of fish culture system for their development (Goddek et al., 2019).

The types of plants used in the aquaponics system can be vegetable plants, fruit plants, aquatic plants (aquascape), flower plants or other aquatic plants. Ghaly et al. (2005) reported that five types of plants, including Medicago sativa L., Trifolium repens L., Avena sativa L., Secale cereale L. and Hordeum vulgare L. were able to reduce total solids, $\mathrm{COD}, \mathrm{NO}_{3}-\mathrm{N}, \mathrm{NO}_{2}-\mathrm{N}$, phosphate and potassium ranging from $54.7 \%$ to $91.0 \%, 56.0 \%$ to $91.5 \%, 82.9 \%$ to $98.1 \%, 95.9 \%$ to $99.5 \%, 54.5 \%$ to $93.6 \%$ and $99.6 \%$ to $99.8 \%$. Handajani et al. (2018) also postulated that Echinodorus palaefolius (J. F. Macbr) could utilize N and P in Anguilla bicolor culture. Water remediation with E. amazonicus and E. palaefolius significantly reduced TAN, $\mathrm{NO}_{2}, \mathrm{NO}_{3}$, and $\mathrm{PO}_{4}$ concentrations in effluent of fish culture system. Unfortunately, no one has used E. palaefolius as a phytoremediator agent in the aquaponic system of catfish culture. Thus, that system is expected to improve the performance of fish production.

The purpose of this study was to evaluate the capacity of water Jasmine/Mexican Sword [Echinodorus palaefolius (J. F. Macbr.)] plants as phytoremediation agents in aquaponics systems in reducing waste of catfish culture system.

\section{Materials and Methods}

\subsection{Preparation of containers, fish, and plants}

Two types of containers were used in this experiment for catfish fry and E. palaefolius cultivation. Twelve catfish fries were reared in containers filled with $40 \mathrm{~L}$ of water, while $E$. palaefolius was maintained in a tub with volume of $38 \mathrm{~cm} \times 12 \mathrm{~cm} \times 30 \mathrm{~cm}$ in length, completed with sand as a planting medium at the bottom of the tub. Meanwhile, this experiment used catfish fries (5.14 $\mathrm{g} \pm$ $0.45 \mathrm{~g}$ ) obtained from a group of fish farmers in Malang Regency, with a stocking density of one fish per liter. The placement of fish in the experimental unit was carried out randomly. Before the treatment, catfish was conditioned for $5 \mathrm{~d}$, fed diet of $30 \%$ of protein with a feeding rate of $3 \%$ of the biomass. The frequency of feeding was conducted in the morning (06.00), afternoon (12.00) and evening (18.00) for $30 \mathrm{~d}$. During the conditioning period, the health and vitality of catfish were controlled so that they were still suitable as a sample. Moreover, the aquatic plants obtained from ornamental aquatic plant cultivators were adapted in a fibre bath for $5 \mathrm{~d}$ before use.

\subsection{Experimental design and data analysis}

This study used a completely randomized design with four treatments with three replications. These treatments differed among teach other in the stocking density of E. palaefolius: $0 \mathrm{~g} \mathrm{~m}^{-2}$ (T1), $150 \mathrm{~g} \mathrm{~m}^{-2}$ (T2), $250 \mathrm{~g} \mathrm{~m}^{-2}$ (T3) and $350 \mathrm{~g} \mathrm{~m}^{-2}$ (T4). Each treatment was repeated three times.ANOVA and F test used the SPSS version 21 with $95 \%$ confidence level, then further tested using the Duncan's multiple range test to determine whether significant variation among treatment means the treatment effect on each tested variable (Adinurani, 2016).

\subsection{Measurements}

Water quality measurements were carried out for $30 \mathrm{~d}$ (day) after introducing water plants. Water quality parameters were measured every day including temperature, $\mathrm{pH}$, dissolved oxygen (DO), while total amoniacal nitrogen (TAN), nitrate nitrogen $\left(\mathrm{NO}_{3}-\mathrm{N}\right)$, nitrite nitrogen $\left(\mathrm{NO}_{2}\right)$, phosphate phosphorus $\left(\mathrm{PO}_{4}-\mathrm{P}\right)$, total suspended solids (TSS), once a week (1 wk=7 d) following Enduta et al., 2011. Measurement of TAN, nitrite, nitrate, and orthophosphate was carried out using a spectrophotometer referring to Rice et al. (2017). The following measures were taken: survival rate (SR), total feed consumption, specific growth rate (SGR), absolute length (Al), and feed conversion ratio (FCR) to determine the growth performance of catfish (Liu et al., 2016; Nhan et al., 2019) using Equation (1) to Equation (4):

$$
\begin{array}{ll}
\operatorname{SGR}\left(\% \mathrm{~d}^{-1}\right) & =\frac{\text { Wo }-\mathrm{Wt}}{\mathbf{t}} \\
\operatorname{Al}(\mathrm{cm})=\mathrm{Lt}-\mathrm{L} 0 & \\
\text { FCR } & =\frac{\mathrm{F}}{\mathrm{Wt}-\mathrm{Wo}}
\end{array}
$$

Note:SGR = Specific growth rate $\left(\% \mathrm{~d}^{-1}\right) ; \mathrm{FCR}=$ Feed conversion ratio; $\mathrm{Al}=$ Absolute lenght $(\mathrm{cm}) ; \mathrm{F}=$ Feed consumption during cultivation (kg); W0 = Initial weight (g); $\quad$ Wt $=$ Final weight (g); W0 = Initial lenght (cm)

$\mathrm{Wt}=$ Final lenght $(\mathrm{cm}) ; \mathrm{t}=$ Time $($ day $)$

$\mathrm{SR}(\%)=\frac{N t}{N o} \times 100$

Note:SR = Survival rate (\%);No= Initial number of fish; $\mathrm{Nt}=$ Final number of fish

The calculation of nutrient removal was carried out every $7 \mathrm{~d}$, such as TAN, $\mathrm{NO}_{3}, \mathrm{NO}_{2}$ and $\mathrm{PO}_{4}$ (Enduta et al., 2011). The water plant parameters, including wet biomass, were measured at the beginning and end of the experiment. At the beginning and end of the investigation, the total $\mathrm{N}$ and $\mathrm{PO}_{4}-\mathrm{P}$ in plant tissue were analyzed (Amalia et al., 2014).

\subsection{Nutrient removal efficiency}

During the experiment, there was a loss of nutrients in the water. The amount of nutrient reduction could be calculated by the following Equation (5) (Zhou et al., 2006).

$N R=\frac{(C a-C b)}{C a} \times 100$

Note:NR = nutrient removal (\%); $\mathrm{Ca}=$ nutrient concentration of influent $\left(\mathrm{mg} \mathrm{L}^{-1}\right)$; $\mathrm{Cb}=$ nutrient concentration of effluent (mg L ${ }^{-1}$ )

\section{Result and discussion}

\subsection{Result}

\subsubsection{Water quality and nutrient removal efficiency}

Measurement of water quality parameters, including temperature, $\mathrm{pH}$, dissolved oxygen (DO), total suspended solids (TSS), total ammonia nitrogen (TAN), ammonia $\left(\mathrm{NH}_{3}\right)$, ammonium $\left(\mathrm{NH}_{4}\right)$, nitrate nitrogen $\left(\mathrm{NO}_{3}-\mathrm{N}\right)$, 
nitrite nitrogen $\left(\mathrm{NO}_{2}-\mathrm{N}\right)$, orthophosphate $\left(\mathrm{PO}_{4}-\mathrm{P}\right)$ were

examined for $30 \mathrm{~d}$ of catfish rearing (Table 1$)$.

Tabel 1. Water quality in catfish media during $30 \mathrm{~d}$ observation

\begin{tabular}{|c|c|c|c|c|c|}
\hline Variable & T1 & T2 & T3 & T4 & Optimum Reference \\
\hline Temperature $\left({ }^{\circ} \mathrm{C}\right)$ & 26.50 to 29.30 & 26.30 to 28.70 & 26.80 to 28.92 & 26.30 to 27.68 & 25 to $30{ }^{\circ} \mathrm{C}$ (Siqwepu et al., 2020) \\
\hline $\mathrm{DO}\left(\mathrm{mg} \mathrm{L}^{-1}\right)$ & 4.75 to 5.13 & 4.65 to 5.60 & 4.75 to 5.60 & 4.27 to 5.53 & > $3 \mathrm{mg} \mathrm{L}^{-1}$ (Siqwepu et al., 2020) \\
\hline $\mathrm{pH}$ & 7.37 to 7.52 & 7.90 to 8.10 & 7.95 to 8.10 & 7.85 to 8.03 & 6.5 to 8 (Siqwepu et al., 2020) \\
\hline TSS (mg L ${ }^{-1}$ ) & 4.67 to 5.44 & 4.40 to 4.56 & 4.06to 4.45 & 4.00to 4.56 & < 80 (Siqwepu et al., 2020) \\
\hline TAN (mg L $\left.{ }^{-1}\right)$ & 0.15 to 0.47 & 0.15 to 0.27 & 0.15 to 0.27 & 0.15 to 0.25 & $<0.27$ (Elesho et al., 2021) \\
\hline $\mathrm{NO}_{2}-\mathrm{N}\left(\mathrm{mg} \mathrm{L}^{-1}\right)$ & 0.05 to 0.35 & 0.05 to 0.31 & 0.05 to 0.27 & 0.05 to 0.24 & $<0.21$ (Elesho et al., 2021) \\
\hline $\mathrm{NO}_{3}-\mathrm{N}\left(\mathrm{mg} \mathrm{L}^{-1}\right)$ & 14.64 to 49.67 & 14.64 to 47.60 & 14.64 to 43.28 & 14.64 to 45.27 & $<53$ (Elesho et al., 2021) \\
\hline $\mathrm{PO}_{4}-\mathrm{P}\left(\mathrm{mg} \mathrm{L}^{-1}\right)$ & 0.65 to 9.96 & 0.65 to 8.85 & 0.65 to 8.63 & 0.65 to 8.51 & $<10$ (Elesho et al., 2021) \\
\hline
\end{tabular}

Figure 1 shows the trend of nutrient removal efficiency every $7 \mathrm{~d}$ for each treatment. The removal efficiency of $\mathrm{NO}_{3}$ and $\mathrm{PO}_{4}$ in all treatments tended to increase every week, except at $\mathrm{T} 3\left(250 \mathrm{~g} \mathrm{~m}^{-2}\right)$ that the removal of phosphate decreased at $2^{\text {nd }}$ wk and nitrate at $4^{\text {th }}$ wk. The
TAN removal efficiency for all treatments was almost the same level at week two, and then in the following week, it tended to increase. On the other hand, $\mathrm{NO}_{2}$ removal efficiency fluctuated for all treatments.

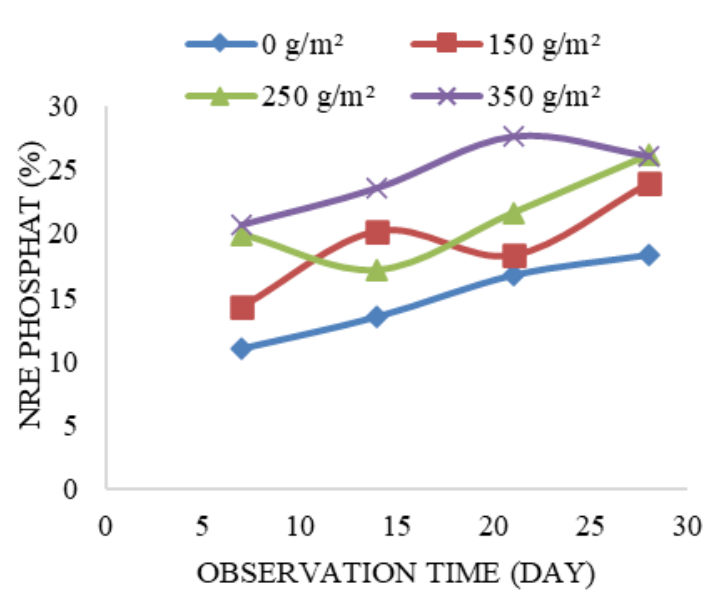

A

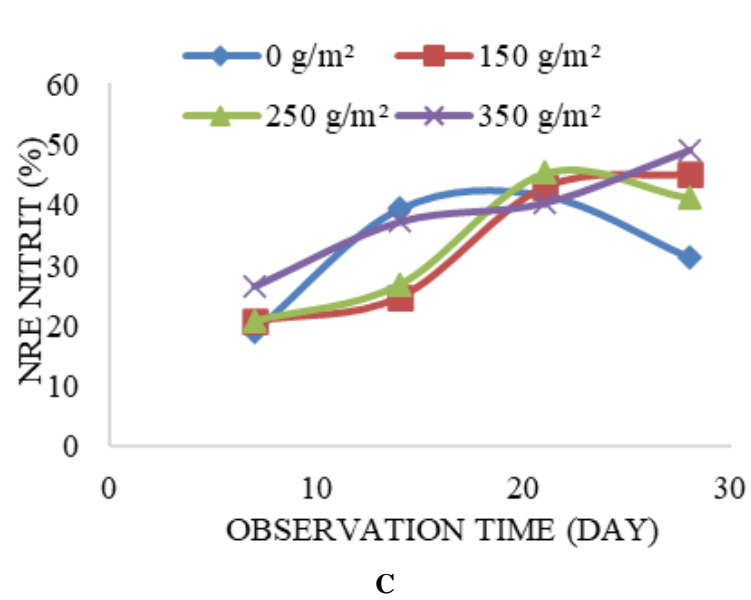

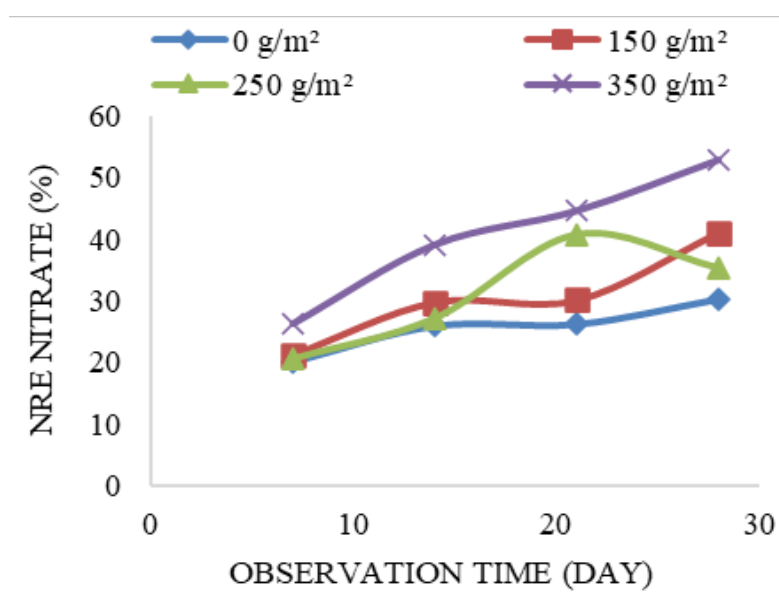

B

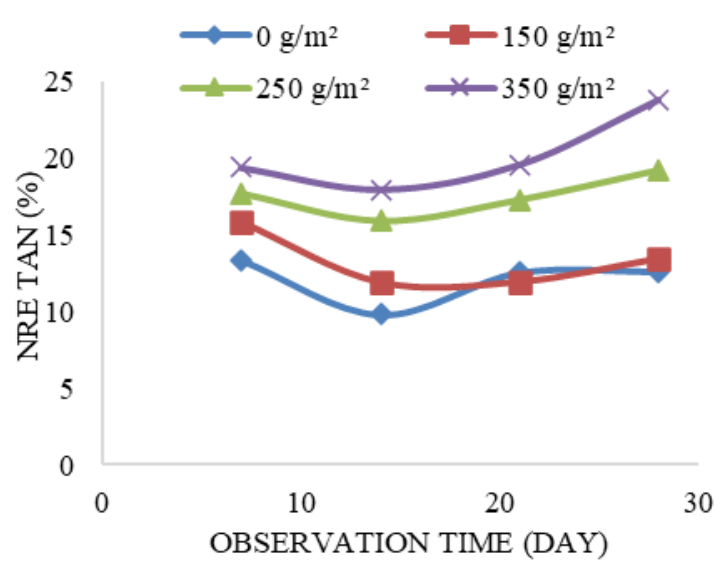

D

PHOSPHATE-P NITRATE-N

Figure 1. Nutrient Removal efficiency (\%) Phosphate-P (A), Nitrate-N (B), Nitrite-N (C) and Total Ammonia Nitrogen TAN (D)

\subsubsection{Catfish growth performance}

The growth performance of catfish fry consisting of survival, specific growth rate, absolute length, total feed consumption, and feed conversion on maintenance for $30 \mathrm{~d}$ is presented in Table 2. The statistical analysis of results showed that Treatments, T3 and T4 almost significantly differences between treatments $(P<0.05)$ varied from other treatments, except for survival, which was not significantly different. But only absolute length of fishes of T4, T3 and T2 had significant $(P<0.05)$ difference from that of $\mathrm{T} 1$. (E. palaefolius, $350 \mathrm{~g} \mathrm{~m}^{-2}$ ) showed the 
highest value for specific growth and absolute length and the lowest feed conversion rate.

Table 2. Growth performance of catfish cultured under aquaponics system

\begin{tabular}{|c|c|c|c|c|}
\hline Variable & $\mathrm{T} 1$ & $\mathrm{~T} 2$ & $\mathrm{~T} 3$ & $\mathrm{~T} 4$ \\
\hline Specific growth rate (\%) & $2.53 \pm 3.74^{b}$ & $3.18 \pm 5.54^{b}$ & $3.84 \pm 4.93^{\mathrm{a}}$ & $4.00 \pm 2.73^{\mathrm{a}}$ \\
\hline Absolute length (cm) & $3.06 \pm 0.46^{\mathrm{b}}$ & $4.57 \pm 0.16^{\mathrm{a}}$ & $4.66 \pm 0.16^{\mathrm{a}}$ & $4.72 \pm 0.15^{\mathrm{a}}$ \\
\hline Feed consumption (g) & $106.53 \pm 4.23$ & $173.63 \pm 2.63$ & $158.40 \pm 6.39$ & $165.83 \pm 5.06$ \\
\hline Feed conversion ratio & $0.54 \pm 0.8^{\mathrm{b}}$ & $0.43 \pm 0.02^{b}$ & $0.39 \pm 0.02^{\mathrm{a}}$ & $0.35 \pm 0.01^{\mathrm{a}}$ \\
\hline Survival rate (\%) & $100.00 \pm 0.00$ & $100.00 \pm 0.00$ & $100.00 \pm 0.00$ & $100 \pm 0.00$ \\
\hline
\end{tabular}

The different letters in each row showed significant differences $(P<0.05)$

\subsubsection{Plant growth performance}

The statistical analysis results showed significant differences of plant growth parameters of $\mathrm{T} 4$ and $\mathrm{T} 3 \mathrm{had}$ significant $(P<0.05)$ differences from the same of T1 but not in the case of plant height. The $\mathrm{T} 4\left(350 \mathrm{~g} \mathrm{~m}^{-2}\right)$ had the highest biomass gain, daily growth, nitrogen retention and phosphorus retention. Meanwhile, plant height was not significantly different.

Table 3.Plant growth performance (E. palaefolius)

\begin{tabular}{llll}
\hline Variable & T2 & T3 & T4 \\
\hline$\Delta$ biomass (g) & $84.67 \pm 5.25^{\mathrm{a}}$ & $109.67 \pm 2.60^{\mathrm{b}}$ & $112.67 \pm 2.89^{\mathrm{c}}$ \\
Daily growth (g) & $2.07 \pm 0.07^{\mathrm{a}}$ & $3.37 \pm 0.49^{\mathrm{b}}$ & $4.97 \pm 0.83^{\mathrm{c}}$ \\
Plant height (cm) & $20.48 \pm 3.56$ & $29.25 \pm 1.79$ & $48.97 \pm 4.53$ \\
Nitrogen retention (g) & $99.87 \pm 4.39^{\mathrm{a}}$ & $143.84 \pm 0.74^{\mathrm{b}}$ & $178.11 \pm 6.53^{\mathrm{c}}$ \\
Phosphorus retention (g) & $68.23 \pm 3.62^{\mathrm{a}}$ & $121.43 \pm 0.39^{\mathrm{b}}$ & $149.12 \pm 1.64^{\mathrm{c}}$
\end{tabular}

The different letters in each row showed significant differences $(P<0.05)$

\subsection{Discussion}

The maintenance of catfish fry by applying aquaponics technology was greatly influenced by environmental factors, including temperature, $\mathrm{pH}$, and dissolved oxygen. The higher the temperature of the media was, the higher the metabolic rate of the fish was so that the fish appetite increased, which means an increase in the toxicity of excreted metabolic waste. The range of temperatures in this study was still in good condition for catfish growth (26.30 ${ }^{\circ} \mathrm{C}$ to $28.92{ }^{\circ} \mathrm{C}$ ). According to Siqwepu et al. (2020), the optimal temperature ranged for catfish is $25^{\circ} \mathrm{C}$ to $30^{\circ} \mathrm{C}$. Elesho et al. (2021) support that catfish can grow well at $25^{\circ} \mathrm{C}$ to $31^{\circ} \mathrm{C}$.

The $\mathrm{pH}$ value during the observation period ranged from 7.37 to 8.10 . This $\mathrm{pH}$ value was in the optimum range of catfish growth, accounting for 6.5 to 9 (Ajiboye et al., 2015; Hasan et al., 2020). Moreover, dissolved oxygen in this study ranged from $3.8 \mathrm{mg} \mathrm{L}^{-1}$ until $7.8 \mathrm{mg} \mathrm{L}^{-1}$ (Ekawati et al., 2021), and this value was in the tolerance range for catfish growth, namely $>3 \mathrm{mg} \mathrm{L}^{-1}$ (Siqwepu et al., 2020). Meanwhile, according to Elesho et al. (2021), dissolved oxygen for catfish must be above $4 \mathrm{mg} \mathrm{L}{ }^{-1}$ which has the similarity with the present findings.

During the present study, it was found that TSS remained still in the optimal range, supporting catfish survival and plant growth. The optimal range of TSS values was $25 \mathrm{mg} \mathrm{L}^{-1}$ to $80 \mathrm{mg} \mathrm{L}^{-1}$ (Oseni et al., 2018). The high TSS value could inhibit the growth of aquatic plants because it interferes with the plant's photosynthetic process. According to Sanjoto et al. (2020), suspended and dissolved materials in the water are not toxic. However, if they are in excessive amount, they can increase the turbidity value, further inhibiting sunlight penetration into the water column and ultimately affecting the photosynthetic process in the water (Oseni et al., 2018).

In this study, the measured ammonia was one of the part of total ammonia nitrogen (TAN). The TAN value ranged from $0.15 \mathrm{mg} \mathrm{L}^{-1}$ to $0.47 \mathrm{mg} \mathrm{L}^{-1}$ (Table 1), lower than the research of (Akinbile and Yusoff, 2012), which used Eichhornia crassipes Martand, Pistia stratiotes L. as remediating agents. The results of TAN, $\mathrm{NH}_{3}$ and $\mathrm{NH}_{4}$ shown ranged from $1.34 \mathrm{mg} \mathrm{L}^{-1}$, to $1.79 \mathrm{mg} \mathrm{L}^{-1} ; 0.14$ $\mathrm{mg} \mathrm{L} \mathrm{L}^{-1}$, to $0.2 \mathrm{mg} \mathrm{L}^{-1}$ and $0.13 \mathrm{mg} \mathrm{L}^{-1}$, and $0.22 \mathrm{mg} \mathrm{L}^{-1}$, respectively.

The water quality in the phytoremediation-based recirculation system was optimal because plants could utilize fish culture waste as nutrients for their growth. According to Effendi et al. (2015), water spinach can reduce TAN by $84.6 \%, 34.8 \%$ of $\mathrm{NO}_{3}$ and $44.4 \%$ of $\mathrm{PO}_{4}$. On the other hand, Delis et al. (2015) reported that Vetiver grass [Chrysopogon zizanioides (L.) Roberty] could reduce TAN by $48.36 \%$ and $\mathrm{PO}_{4}$ by $19.94 \%$. In this study, the ability of E. palaefolius was the highest in reducing TAN, $\mathrm{NO}_{2}, \mathrm{NO}_{3}$, and $\mathrm{PO}_{4}$ by of T4. The percentage of removal of TAN, $\mathrm{NO}_{2}, \mathrm{NO}_{3}$, and $\mathrm{PO}_{4}$ on $28^{\text {th }} d$ was $23.80 \%$; $48.91 \%$; $52.99 \%$; and $27.63 \%$, respectively. Meanwhile, the lowest nutrient removal by of T1, were TAN on $14^{\text {th }} d$ was $9.8 \%$; while $\mathrm{NO}_{2}$ on $7^{\text {th }} d$ was $19.07 \%$; $\mathrm{NO}_{3}$ on $7^{\text {th }} d$ was $19.97 \%$, and $\mathrm{PO}_{4}$ was $11.05 \%$ on $7^{\text {th }}$ d. Plants as phytoremediators utilize ammonium and nitrate, where the primary source of inorganic nutrients came through plant roots (Enduta et al., 2011), while it is not toxic for fish. When the water conditions are sufficiently oxidized, ammonia will be converted into an intermediate product, namely nitrite $\left(\mathrm{NO}_{2}\right)$.

Nitrite is a relatively unstable compound because, with sufficient oxygen, it will be easily oxidized to nitrate by Nitrobacter. The nitrite concentration in this research could still be within tolerable levels by fish, although it increased because this compound is unstable. Their changes in the system could be overcomed with sufficient oxygen supply so that the eels can still grow well. According to Van Rijn (2013), in the circulating system, the nitrite concentration should not exceed $10 \mathrm{mg} \mathrm{L}^{-1}$ for an extended period, and in most cases it should remain below $1 \mathrm{mg} \mathrm{L}^{-1}$. According to Elesho et al. (2021), nitrite concentration must be $<0.21 \mathrm{mg} \mathrm{L}^{-1}$ in water media. The Nitrobacter bacteria then oxidizes nitrite $\left(\mathrm{NO}_{2}\right)$ to produce nitrate $\left(\mathrm{NO}_{3}\right)$.

Furthermore, nitrate is the end product of the nitrogen cycle and a compound that is not harmful to fish and a source of nutrients for plants other than $\mathrm{NH}_{4}$. The nitrate 
concentration in this study was still supportive for catfish life because it ranged from $14.64 \mathrm{mg} \mathrm{L}^{-1}$ to $49.67 \mathrm{mg} \mathrm{L}^{-1}$. The research results by Elesho et al. (2021) on the rearing system of catfish, $\mathrm{NO}_{3}$ was $53 \mathrm{mg} \mathrm{L}^{-1}$, while Jaeger et al. (2019) recommended that the $\mathrm{NO}_{3}$ concentration not exceed $50 \mathrm{mg} \mathrm{L}^{-1}$ in waters used for fish farming. High concentrations of $\mathrm{NO}_{3}$ can result in algae blooms which cause a decrease in $\mathrm{pH}$ (Ebeling et al., 2006; Nuwansi et al., 2019). Morning glory (Ipomoea aquatica Forssk.) can reduce total ammonia - nitrogen $\mathrm{N}$, nitrite- $\mathrm{N}$, nitrate- $\mathrm{N}$ and orthophosphate significantly from $78.32 \%$ to $85.48 \%$, $82.93 \%$ to $92.22 \%$, and $79.17 \%$ to $87.10 \%$, respectively, and $75.36 \%$ to $84.94 \%$, whereas by using Chinese broccoli (Brassica oleracea var. alboglabra L.), total ammonia nitrogen could be reduced from $75.85 \%$ to $69.0 \%, 79.34 \%$ to $72.49 \%$ for nitrite-N, $80.65 \%$ to $66.67 \%$ for nitrate-N and $77.87 \%$ to $66.79 \%$ for orthophosphate (Enduta et al., 2011).

The survival rate in this study was $100 \%$. This result was higher when compared to the study by Okomoda et al. (2020) where catfish maintained in a settling tank and aerobic tank as filters gave a survival rate of $82.78 \%$. According to Enduta et al. (2011), the survival rates of African catfish (C. gariepinus) treated with aquaponics technology using kale (Brassica oleracea var. sabellica L.) and caisim (Brassica rapa L. Cv. group Caisin) plants were $94.5 \%$ and $94.2 \%$, respectively. Based on the growth performance data of catfish (Table 2), the density of E. palaefoliusplants as a phytoremediation agent in catfish culture with recirculatory aquaponics affected the growth performance of catfish significantly $(P<0.05)$. The T4 showed the highest growth performance for catfish, including a specific growth rate of $4.00 \%$, an absolute length of $4.72 \mathrm{~cm}$, and feed conversion of 0.4 . This was due to utilizing nutrients from the highest level of catfish culture waste at T4. Therefore, the water quality conditions for catfish rearing were still in good condition to utilize feed more efficiently. According to Pedersen et al. (2012), recirculation application of recirculatory system with water plants, duck weeds (Lemna gibba L), dropped FCR value, increased protein efficiency ratio, and tilapia growth. The FCR in fish farming must be considered because it would affect the cost of feed. Small changes in FCR would have a big effect on the profitability of cultured fish (Liu et al., 2016).

The success of the aquaponics system was inseparable from the growth of E. palaefolius. During the observation period, the development of aquatic ornamental plants showed a positive response to the aquaponics system. That indicated an increase in biomass growth in all treatments and nitrogen retention in plant tissues (Table 3). Freshwater ornamental plants could utilize waste of catfish cultivation waste as a sources of nutrients for their growth. This was evidenced by an increase in the percentage of nutrient removal by plants every $7 \mathrm{~d}$ (Figure 1). The results of biomass growth, daily growth, plant height, nitrogen retention, and phosphorus retention were the highest in T4 with successive values: $112.67 \mathrm{~g}, 4.97 \%, 48.97 \mathrm{~cm}$, $178.11 \mathrm{~g}$, and $149.12 \mathrm{~g}$, respectively.

\section{Conclusion}

Based on our findings, E. palaefoliushas a high potential as a water remediator, proved in C. gariepinus growth performance, nutrient removal capabilities and water quality data. The highest value of those measurements was obtained at $350 \mathrm{~g} \mathrm{~m}^{-2}$ density of E. palaefolius. Moreover, the present results indicated that the higher density of $E$. palaefolius showed a better impact on C. gariepinus development, nutrient removal, and water quality. Hence, further research is still needed for investigating the optimum density of $E$. palaefolius before it can be used in C. gariepinus culture or other fish commodities.

\section{Acknowledgement}

The author would like to thank the Faculty of Agriculture and Animal Science, the University of Muhammadiyah Malang, for the funding given to the Research Blockgrant Program with No SK: E.2.a / 131 / FPP-UMM / II / 2020.

\section{References}

Adinurani PG. Design and Analysis of Agro Trial Data: Manual and SPSS. Plantaxia, Yogyakarta, Indonesia

Ajiboye AO, Awogbade AA, and Babalola OA. 2015. Effects of water exchange on water quality parameters, nutrient utilization and growth of African catfish (Clarias gariepinus). Int. J. Phytoremediation.,6(5):57-60.

Akinbile CO, and Yusoff MS. 2012. Assessing water hyacinth (Eichhornia crassopes) and lettuce (Pistia stratiotes) effectiveness in aquaculture wastewater treatment. Int. J. Phytoremediation.,14(3):201-211.

Amalia F, Nirmala K, Harris E, and Widiyanto T. 2014. The ability of Lemna (Lemna perpusilla Torr.) as a phytoremediator to absorb nitrogen waste in the cultivation of catfish (Clarias gariepinus) in the recirculation system. Jurnal Limnotek,21(2):185-192.

Bureau DP, and Hua K. 2010. Towards effective nutritional management of waste outputs in aquaculture, with particular reference to salmonid aquaculture operations. Aquac. Res.,41(5):777-792.

Delis PC, Effendi H, Krisanti M, and Hariyadi S. 2015. Treatment of aquaculture wastewater using Vetiveria zizanioides (Liliopsida, Poaceae). Aquacult. Aquarium Conserv. Legis., 8(4):616-625.

Ebeling JM, Timmons MB, and Bisogni J. 2006. Engineering analysis of the stoichiometry of photoautotrophic, autotrophic, and heterotrophic removal of ammonia-nitrogen in aquaculture systems. Aquaculture,257(1-4):346-358.

Effendi H, Amalrullah Utomo B, Maruto Darmawangsa G, and Sulaeman N. 2015. Combination of water spinach (Ipomea aquatica) and bacteria for freshwater cryfish red claw (Cherax quadricarinatus) culture wastewater treatment in aquaponic system. J. Adv. Biology,6(3):1072-1078.

Ekawati AW, Ulfa SM, Dewi CSU, Aziz A, Amin LNmS, Yanuar AT, and Kurniawan A. 2021. Analysis of aquaponic-recirculation aquaculture system (A-Ras) application in the catfish (Clarias gariepinus) aquaculture in Indonesia. Aquaculture,21(3):93-100.

El-Shafai SA, El-Gohary FA, Naser FA, van der Steen P, and Gijzen HJ. 2007. Nitrogen recovery in an integrated system for wastewater treatment and tilapia production. Environmentalist, 27(2):287-302. 
Elesho FE, Sutter DAH, Swinkels MAC, Verreth JAJ, Kröckel S, and Schrama JW. 2021. Quantifying methionine requirement of juvenile African catfish (Clarias gariepinus). Aquaculture, 532:(736020): 1-11.

Enduta A, Jusoh A, Ali Na, and Wan Nik W. 2011. Nutrient removal from aquaculture wastewater by vegetable production in aquaponics recirculation system. Desalin Water Treat., 32(13):422-430.

FAO. 2018. FAO Yearbook. Fishery and Aquaculture Statistics 2018, Rome.

Ghaly A, Kamal M, and Mahmoud N. 2005. Phytoremediation of aquaculture wastewater for water recycling and production of fish feed.Environ Int., 31(1):1-13.

Goddek S, Joyce A, Wuertz S, Körner O, Bläser I, Reuter M and Keesman KJ. 2019. Decoupled aquaponics systems. In: Goddek S, Joyce A, Kotzen B and Burnell GM (Eds.) Aquaponics Food Production Systems: Combined Aquaculture and Hydroponic Production Technologies for the Future. Springer International Publishing, Cham, Switzerland pp 201-229.

Handajani H, Widanarni W, Budiardi T, Setiawati M, and Sujono S. 2018. Phytoremediation of Eel (Anguilla bicolor bicolor) rearing wastewater using amazon sword (Echinodorus amazonicus) and water jasmine (Echinodorus palaefolius). OmniAkuatika, 14(2):43-51.

Hasan M, Mawa Z, Ul-Hassan H, Rahman M, Tanjin S, Ahmed Abro N, Gabol K, Bashar M, Jasmine S, and Ohtomi J. 2020. Impact of eco-hydrological factors on growth of the Asian stinging catfish Heteropneustus fosslis (Bloch, 1794) in a Wetland Ecosystem. Egypt. J. Aquat. Biol. Fish, 24(5):77-94.

Hlordzi V, Kuebutornye FKA, Afriyie G, Abarike ED, Lu Y, Chi S, and Anokyewaa MA. 2020. The use of Bacillus species in maintenance of water quality in aquaculture: A review.Aquac. Rep,18(100503):1-12.

Jaeger C, Foucard P, Tocqueville A, Nahon S, and Aubin J. 2019. Mass balanced based LCA of a common carp-lettuce aquaponics system. Aquac Eng., 84:29-41.

Keramat A. 2011. Reduction in the environmental impact of waste discharged by fish farms through feed and feeding. Rev Aquac, 3:19-26.

Liu H, Zhu X, Yang Y, Han D, Jin J, and Xie S. 2016. Effect of substitution of dietary fishmeal by Soya Bean meal on different sizes of Gibel Carp (Carassius auratus gibelio): nutrient digestibility, growth performance, body composition and morphometry.Aquac. Nutr .22(1):142-157.

Makori AJ, Abuom PO, Kapiyo R, Anyona DN, and Dida GO. 2017. Effects of water physico-chemical parameters on Tilapia (Oreochromis niloticus) growth in earthen ponds in Teso North Sub-County, Busia County.Fish Aquatic Sci, 20(1):20-30.

Monsees H, Keitel J, Paul M, Kloas W, and Wuertz S. 2017. Potential of aquacultural sludge treatment for aquaponics: evaluation of nutrient mobilization under aerobic and anaerobic conditions. Aquac. Environ. Interact., 9(1):9-18.
Nhan HT, Tai NT, Liem PT, Ut VN, and Ako H. 2019. Effects of different stocking densities on growth performance of Asian swamp eel Monopterus albus, water quality and plant growth of watercress Nasturtium officinale in an aquaponic recirculating system. Aquaculture, 503:96-104.

Nuwansi KKT, Verma AK, Rathore G, Prakash C, Chandrakant MH, and Prabhath GPWA. 2019. Utilization of phytoremediated aquaculture wastewater for production of koi carp (Cyprinus carpio var. koi) and gotukola (Centella asiatica) in an aquaponics. Aquaculture, 507:361-369.

Okomoda VT, Musa SO, Tiamiyu LO, Solomon SG, Oladimeji AS, Hassan A, Alabi KI, and Abol-Munafi AB. 2020. Fermentation of hydrothermal processed Jatropha curcas Kernel: Effects on the performance of Clarias gariepinus (Burchell, 1822) fingerlings. Aquac. Rep., 18(100428): 1-7

Oseni OM, Dada OE, Okunlola GO, and Ajao AA. 2018. Phytoremediation potential of Chromolaena odorata (L.) king and robinson (Asteraceae) and Sida acuta Burm. f. (Malvaceae) grown in lead-polluted soils. Jordan J. Biol. Sci., 11(4):355-360.

Pedersen L-F, Suhr KI, Dalsgaard J, Pedersen PB, and Arvin E. 2012. Effects of feed loading on nitrogen balances and fish performance in replicated recirculating aquaculture systems. Aquaculture, 338-341:237-245.

Rice EW, Baird RB, and Eaton AD. 2017. Standard Methods for the Examination of the Water and Wastewater, 23rd ed., Washington DC (US).

Sanjoto TB, Elwafa AH, Tjahjono H, and Sidiq WABN. 2020. Study of total suspended solid concentration based on Doxaran algorithm using Landsat 8 image in coastal water between Bodri River estuary up to east flood canal Semarang City. IOP Conf. Ser. Earth Environ. Sci., 561(012053):1-7.

Siqwepu O, Salie K, and Goosen N. 2020. Evaluation of chelated iron and iron sulfate in the diet of African catfish, Clarias gariepinus to enhance iron excretion for application in integrated aquaponics systems.J World Aquac Soc, 51(4):1034-1053.

Somerville C, Cohen M, Pantanella E, Stankus A, and Lovatelli A. 2014. Small-Scale Aquaponic Food Production. Integrated Fish and Plant Farming, Rome.

Van Rijn J. 2013. Waste treatment in recirculating aquaculture systems. Aquac Eng., 53:49-56.

Yavuzcan YH, Robaina L, Pirhonen J, Mente E, Domínguez D, and Parisi G. 2017. Fish welfare in aquaponic systems: Its relation to water quality with an emphasis on feed and faeces-A Review. Water, 9(1)13:1-17

Zahidah Z, Andriani Y, Dhahiyat Y, Nurruhwati I, Sahidin A, Hamdani H, and Victoria SM. 2018. Inorganic nitrogen absorption in the aquaponics farming of Sangkuriang Catfish (Clarias gariepinus) at uneven retention periods. Jurnal Akuakultur Indonesia, 17(2):130-136.

Zhou Q, He SL, He X, Huang XF, Picot B, Li XD, and Chen G. 2006. Nutrients removal mechanisms in high rate algal pond treating rural domestic sewage in East China.Water Sci Technol Water Supply, 6(6):43-50. 